\title{
Identifying the determinants of outward foreign direct investment decisions of South African retail enterprises investing into Africa
}

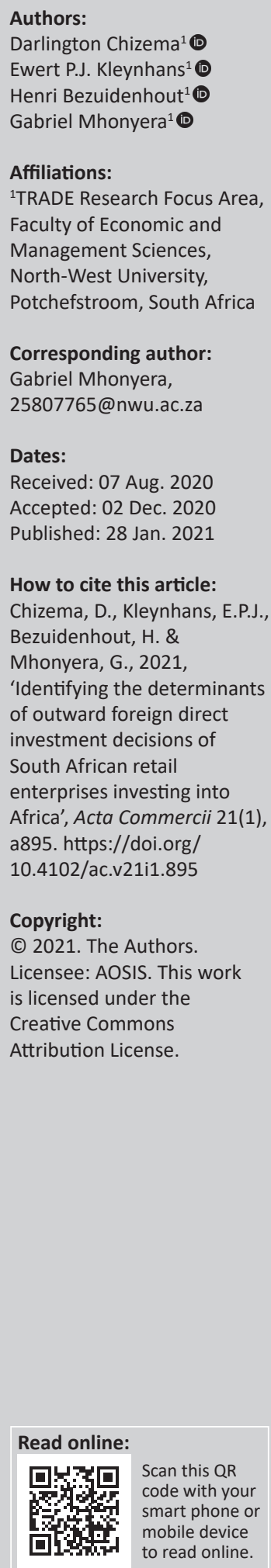

Orientation: Whilst Africa is a lucrative market with many opportunities for all types of retailers, expanding into the continent is not without its own challenges. Therefore, foreign direct investors have to make strategic decisions.

Research purpose: The main aim of this article was to identify the determinants of outward foreign direct investment (FDI) decisions of five major South African retail enterprises with a significant FDI footprint in Africa.

Motivation of the study: Although there has been a robust expansion in the South African retail sector outward FDI and that of Africa in general, the empirical literature on retail sector outward FDI from the perspective of African countries is sparse. In fact, most of the retail sector outward FDI research in existence has been focussed on developed countries, with little attention being paid to developing countries.

Research design, approach and method: This research article stems from a study conducted by Chizema, which investigated the motivation of South African retailers who are making inroads into the rest of Africa. By using a mixed-method research technique, this article identifies the determinants of outward FDI decisions of five major South African retailers with a substantial FDI footprint in Africa.

Main findings: For all the retailers considered in this article, the most significant push determinants were identified as market-seeking, efficiency-seeking and ownership advantages. Similarly, the most significant pull determinants were identified as market size, political and macro-economic stability, profitability and growth prospects, and trade and investment openness. The results also revealed that the risk of investing in the African retail sector is commonly centred on the lack of infrastructure, political uncertainty and bureaucratic procedures.

Practical and managerial implications: The knowledge emanating from this article may assist in shaping the outward FDI decisions of prospective retail and other multinational enterprises (MNEs) contemplating to invest in Africa. It may also assist in influencing the design and implementation of policies aimed at attracting FDI in the African continent.

Contribution/value-add: This article seeks to contribute to the knowledge base and to inspire debate on the retail sector outward FDI from the perspective of African countries.

Keywords: Africa; multinational enterprises; outward FDI; outward FDI determinants; retail sector; South Africa.

\section{Introduction}

Foreign direct investment (FDI) is not a new phenomenon. In fact, the significance of FDI as a source of economic growth has increased rapidly over the past decades (Carril-Caccia \& Pavlova 2018). Although many definitions of FDI exist in literature, it is widely accepted that FDI is an investment involving a long-term relationship and reflecting a lasting interest of a resident entity in one country on an enterprise resident in another country (United Nations Conference on Trade and Development [UNCTAD] 1999). The 'lasting interest' signals a substantial level of control in the management of the FDI enterprise and the continuation of an innate relationship between the foreign direct investor and the FDI enterprise. This is typically evident in the ownership of at least $10 \%$ of the voting rights of an entity resident in one country by an entity resident in another country (Organisation for Economic Co-operation and Development 2002). 
In addition to strategic decisions pertaining to the level of control over its FDI engagements, an entity contemplating to pursue a foreign market through FDI faces strategic decisions relating to the mode of foreign market entry (Müller 2006). For instance, an entity may opt for brown-field or green-field investment as a mode of entry into a foreign market. Brownfield investment, also known as mergers and acquisitions (M\&A), entails the purchasing of existing production facilities by a foreign entity in order to establish new production ventures in the host country (Qiu \& Wang 2011). Green-field investment, however, involves the establishment of new production ventures by a foreign entity through construction of new operational facilities from scratch in the host country (Pletikosa 2015).

Even though the role of FDI in driving economic growth and development has been a contested one ever since the United Nations (UN) development decade of the 1960s, there have always been views in favour of and against FDI (Te Velde 2006). In this regard, advocates of FDI have revealed it as a reputable source of capital for developing countries, particularly those geographically located in the African continent, as it is commonly believed that FDI assists in stimulating the convergence between savings and investment (Ajayi 2005). In addition, FDI is understood to set in motion economic growth and productivity increases in the entire economy and, therefore, contributes to variations in economic growth and development performances across countries (Aghion \& Howitt 1998; UNCTAD 2002). However, those against FDI frequently stress the risk of FDI destroying local capabilities and extracting natural resources without significantly compensating poor countries (Te Velde 2006).

Despite the apparent importance of FDI in economic growth and development endeavours, a number of barriers that affect FDI have been widely documented. These barriers include: policy barriers, which define administrative restrictions on the international flow of merchandise and services enforced through tariffs, embargoes or restraints on the repatriation of profits by FDI entities in a host country; weak political and economic environment; poor infrastructure; and lack of industrial base in host countries.

Nevertheless, given the importance attached to FDI, developing countries, more especially, ought to liberalise their investment policies with the aim of attracting the much needed FDI. In light of this, the conclusion of bilateral investment treaties amongst developing countries is increasingly viewed as a tool for enhancing South-South partnership on FDI flows (UNCTAD 1999). South Africa, in particular, is regarded as a major investor in the South-South cooperation through multinational enterprises (MNEs). In fact, since the advent of democracy in 1994, South African firms have had a strong economic and investment footprint throughout the African continent, and this footprint has been proliferating.
During the period 2013-2017, South Africa was ranked as the seventh largest global foreign direct investor in Africa in terms of FDI stock. In 2018, the country was also ranked as the largest FDI home economy and the second largest FDI host economy in Africa (UNCTAD 2019). The expansion in South Africa's level of FDI in Africa is mainly attributed to the conclusion of bilateral trade agreements with a number of African countries, as well as the gradual liberalisation of the country's capital outflow policy. Furthermore, favourable labour practices in other African countries, mostly low wages, have predominantly lured large retail entities in South Africa to invest abroad (UNCTAD 2004).

The growth of FDI in the South African retail sector is believed to have been inspired, to a larger extent, by the need to respond to changing demands and behaviours of customers and the growth in technological sophistication (Myers \& Alexander 2007). This has led to the integration of large South African supermarket chains into the regional value chains. For instance, the largest retail MNE in Africa, Shoprite of South Africa, now has more than 362 retail outlets in 14 African countries other than South Africa (Shoprite 2019).

Although there has been a robust expansion in the South African retail sector outward FDI and that of Africa in general, the empirical literature on retail sector outward FDI from the perspective of African countries is sparse. In fact, most of the research on the retail sector outward FDI in existence has been concentrated on developed countries, with little attention being paid to developing countries. Therefore, this article seeks to contribute to the knowledge base and to inspire debate on the retail sector outward FDI from the perspective of African countries. In this regard, this article progresses from the study of Chizema (2018) utilising a mixed-method research technique to identify the determinants of outward FDI decisions and the challenges faced by five major South African retail enterprises, namely Spar, Retail Z (the retailer requested anonymity), Shoprite, Woolworths and Massmart, with a significant FDI footprint in Africa. The emphasis is on establishing the extent to which push and pull determinants define the South African retail sector outward FDI and the challenges faced when investing in Africa's retail sector.

The rest of this article is structured as follows: firstly, a brief review of the related FDI literature is presented; secondly, a description of the research method and data used to achieve the aims of this article are discussed; thirdly, the results obtained in this article are presented and analysed; and finally, conclusions and recommendations of this article are provided.

\section{Literature review}

As alluded to earlier, the significance of FDI in economic growth and development accomplishments of both developed and developing countries cannot be understated. In fact, the present and previous decades have seen an unprecedented rise in global FDI activities. Besides MNEs 
originating from developed countries, MNEs emerging from developing countries have also actively participated in this growing trend and are ranked amongst some of the most renowned MNEs globally (Paprzycki \& Fukao 2005). However, FDI prospects for 2020-2021 are gloomy. This follows the expectation of an intense decline in global FDI activities as a result of the ongoing COVID-19 pandemic. Whilst COVID-19 is not the only game changer in terms of global FDI, the fourth industrial revolution, the policy shifts towards increased economic nationalism, and sustainability trends will altogether usher in extensive consequences for the configuration of global production in the decade to 2030 (UNCTAD 2020).

\section{Theoretical underpinning of foreign direct investment}

According to Kilic, Bayar and Arica (2014), theories explaining FDI inflows and outflows can be categorised into the following three groups: micro-level FDI theories, which include the oligopolistic markets theory, firm-specific advantages, and the ownership location and internalisation (OLI) theory. The aim of micro-level FDI theories is to try to explain why FDI is preferred by MNEs relative to other modes of entry, such as licensing and exporting; macro-level FDI theories, which are based on institutional analysis, exchange rate theory and capital market theory, amongst others. To explain the determinants and motivations of outward FDI, macro-level FDI theories view FDI as a form of capital flow between different world economies; and development theories, which incorporate theories such as the Japanese FDI theories and the product life-cycle theory.

The OLI theory is, however, most frequently applied in recognising, analysing and enhancing the understanding of the role of outward FDI in the global economy.

\section{The ownership location and internalisation theory}

The OLI theory, also known as the eclectic paradigm model, was put forward by Dunning (1976). In terms of the theory, outward FDI is attributed to three main advantages, namely ownership, location and internalisation. Ownership advantages stipulate that entities invest abroad when they possess certain monopoly ownership advantages that surpass the cost of doing business in a foreign country relative to domestic entities (Dunning 1995). Such monopoly ownership advantages can be in the form of superior technology, economies of scale, and blueprint or patents that permit the establishment of production processes or products that are immune to imitation (Chen 2015).

Location advantages capture potential host countries' specifications, which are significant to the foreign direct investor in determining the country to invest in. Denesia (2010) identified the following three categories of location advantages: firstly, economic advantages, which comprise qualitative and quantitative production factors, market size and transport costs; secondly, political advantages, which refer to direct and indirect government policies that influence FDI flows; and finally, social advantages, which include the geographical distance between the home and host country, as well as cultural diversity.

Whilst the ownership and location advantages provide a basis for choosing FDI over exports, internalisation advantages determine the approach utilised by an entity to penetrate into the foreign market. This is achieved through evaluating the benefits of a wholly owned subsidiary relative to other forms of foreign market entry, such as licensing and franchising. Entities will, therefore, prefer FDI in comparison with franchises and license agreements if the internalisation advantages are higher for cross-border activities.

Notwithstanding the contribution of the OLI theory in explaining the theoretical foundation of FDI, the theory is not free from shortcomings. Particularly, a noticeable concern with the OLI theory is that it requires all the three conditions (i.e. ownership, location and internalisation) to be fulfilled prior to the commencement of FDI initiatives (Surdu, Mellahi \& Glaister 2018). Therefore, the theory fails to account for South-South FDI, as the majority of developing countries still generate and attract FDI in the absence of adequate ownership and location advantages. Consequently, this has led to an expansion of the OLI framework, in order to explain for FDI taking place amongst developing countries, with the investment development path (IDP) theory.

\section{The investment development path theory}

The IDP theory links the net outward investment position of a country to its gross domestic product (GDP) per capita (eds. Dunning \& Narula 1996). The theory proposes that the investment development cycle of a country is contingent upon its level of economic development. In other words, the IDP theory suggests the existence of a systematic correlation between a country's level of development and the nature of FDI that it generates and receives (Dunning 1993; eds. Dunning \& Narula 1996). The initial version of the IDP theory puts forward the existence of an investment development cycle consisting of four stages. However, although the initial version of the IDP theory was adequate in explaining the economic situation during the 1970s and the early 1980s, the intense liberalisation of investment processes has ushered an extensive geographical diversification in the generation and reception of FDI (Durán \& Úbeda 2005). Consequently, the theoretical framework of the IDP has since been readapted to the new institutional context by considering two categories of developed countries that, by their variations, shed light on the fourth and fifth stages of the IDP theory (Dunning 1993).

The pattern of the IDP is shown in Figure 1. According to Dunning and Narula (eds. 1996), a country experiences five stages of economic development characterised by a diverse pattern of outward and inward FDI. Stage 1 is associated with a negative net outward FDI position and refers to 


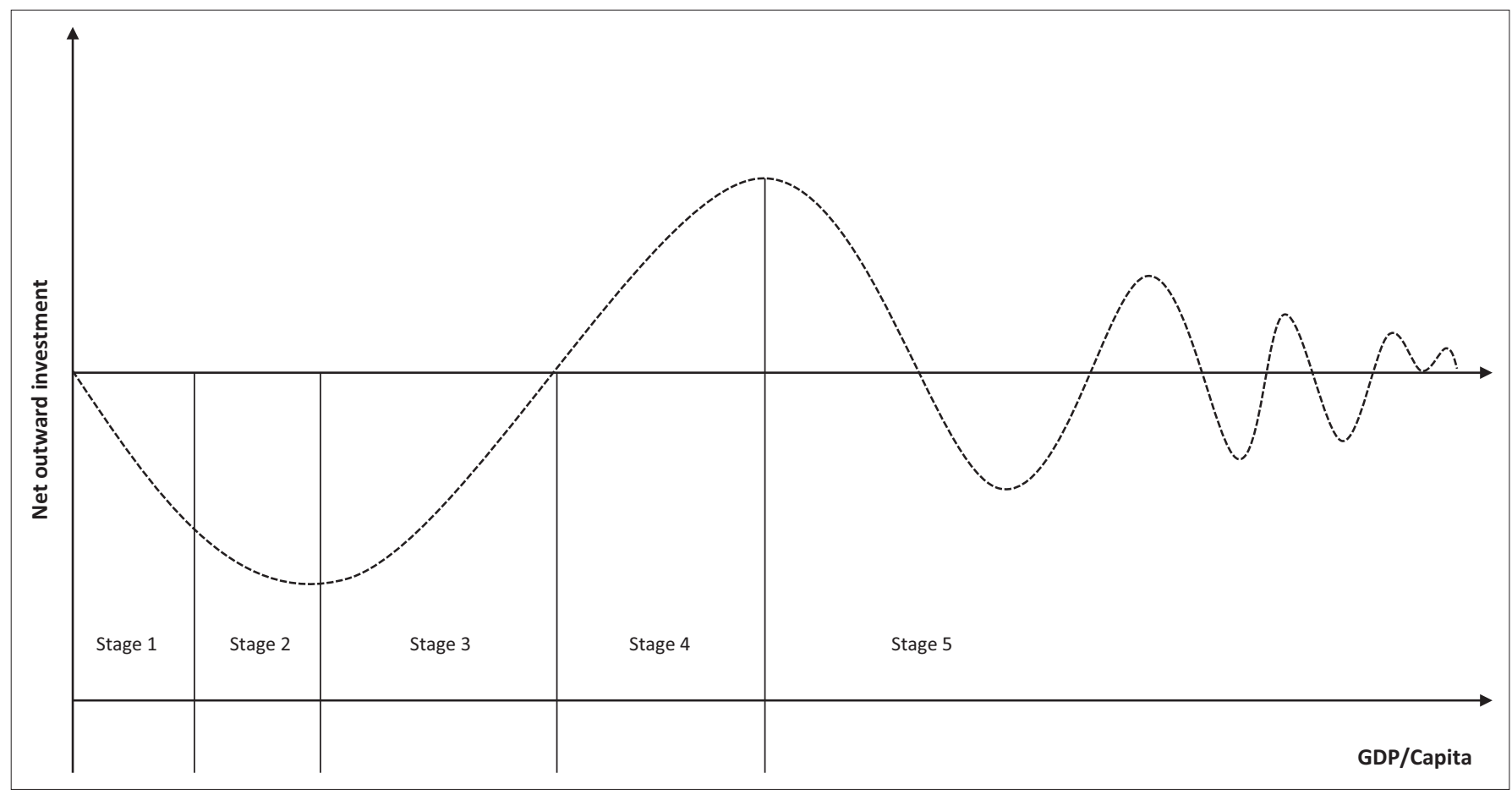

Source: Dunning, J.H. \& Narula, N. (eds.), 1996, Foreign direct investment and governments, Routledge, London GDP, gross domestic product.

FIGURE 1: The pattern of the investment development path.

developing countries that are net FDI receivers. Countries in this stage of development normally possess inadequate locational advantages as a consequence of lack of infrastructure, uneducated labour force, low per capita income and even political as well as economic instability. Hence, both outward and inward FDI are extremely limited, and this inspires foreign direct investors to access such countries through trade, as well as establishing non-equity affiliations with domestic entities.

Stage 2 is a natural progression of the initial stage, which is attributable to the development of some location-specific advantages. This stage is typified by more inward FDI, predominantly targeting the emerging domestic market in consumer goods and infrastructure. However, outward FDI is still limited as domestic entities lack ownership advantages. As such, the net stocks of outward FDI will increasingly become negative, whilst inward FDI stocks grow faster than the GDP.

In stage 3, which includes emerging economies, outward FDI increases and eventually exceeds inward FDI. This results in the improvement of net FDI stock for the first time, despite remaining negative for sometime. Domestic entities develop ownership advantages compared with those of foreign entities. Stronger domestic entities become more competitive in the domestic market, whilst engaging in resource and market-seeking FDI in developing countries and in market and strategic asset-seeking FDI in developed countries.

With deepening trends of outward FDI stock exceeding the inward FDI stock, countries eventually turn into net outward foreign direct investors in stage 4. Domestic entities develop ownership advantages, which permit them to compete with foreign entities in both domestic and foreign markets (Alagidede \& Mensah 2018). Consequently, the increased outward FDI is in the form of efficiency-seeking FDI in countries still in the lower stages of development and strategic asset-seeking FDI in countries in the higher developmental stages. The fifth and final stage of the IDP corresponds to leading developed countries with permanently high stocks of both outward and inward FDI. In this stage, the net outward investment position of countries revolves around zero, alternating between positive and negative balances, depending on the short-term evolution of exchange rates and economic cycles (eds. Dunning \& Narula 1996).

\section{Determinants of outward foreign direct investment}

Whilst home country factors are responsible for driving domestic enterprises to seek for investment prospects elsewhere, it is a general principle that host countries that offer what foreign direct investors are seeking and host countries whose policies are most conducive to FDI activities have a better chance of attracting FDI (UNCTAD 1998). In this regard, two broad determinants, namely, push and pull determinants, shape the outward FDI decisions of MNEs.

\section{Push determinants}

Dunning (1973, 1976, 1995) identified the following primary motivators of outward FDI: (1) market-seeking FDI, which is usually the result of transportation costs and 
government regulations. It aims at supplying local markets in host countries and may represent a higher level of involvement by the firm. This might be after the success of exports or the expansion into a totally new market by the firm; (2) natural resource-seeking FDI, which tends to be location-specific and intended to secure and access cheap raw materials; (3) efficiency-seeking FDI, which is aimed at increasing cost-efficiency or economies of scale by, for example, transferring production to low labour cost countries; and (4) strategic asset-seeking FDI, which is used to build ownership advantages for a firm's long-term expansion plans domestically and internationally.

For both developed and developing countries, scholars have analysed the push determinants of FDI based on the framework of Dunning (1973, 1976, 1995). For instance, an investigation of specific home country determinants that stimulate outward FDI, by Kayam (2009), reveals that insignificant market size, trade conditions, cost of production and local business environment within the home country are the major push determinants that inspire FDI outflows. The findings of Kayam (2009) further revealed that outward FDI from developing countries expands with foreign competition in the domestic market elevated by inward FDI and imports.

In a study of the possible push determinants of outward FDI that propelled MNEs from Malaysia and Thailand to invest in foreign markets during the period 1980-2006, Masron and Shahbudin (2010) identify the following push determinants: home government policies, costs of production, domestic business conditions and market conditions. According to Masron and Shahbudin (2010), these push determinants were all consequential to the decision to invest abroad by domestic investors in Malaysia and Thailand. Furthermore, domestic market conditions emerged as the most influential outward FDI push factor in both countries.

Aykut and Ratha (2004) also analysed the push and pull determinants behind the rise in South-South FDI flows. The identified push determinants include: rising wealth in emerging markets, capital account liberalisation in terms of outward FDI, changes in barriers to trade, conclusion of regional trade agreements, and government policies encouraging outward FDI. Likewise, in describing the major push determinants for the Malaysian outward FDI, Ariff and Lopez (2007) identified rising wealth for individuals and corporations along with a pro-investment government, as some of the leading push determinants.

In addition to push determinants of outward FDI, foreign direct investors consider the host country-specific factors when contemplating to expand into foreign markets.

\section{Pull determinants}

Pull determinants are defined as the factors in the host country that are responsible for attracting FDI into that particular country. These determinants include market size, macro-economic stability, growth prospects, infrastructure, labour costs and trade openness. In fact, a panel data analysis by Ranjan and Agarwal (2011) found the above-mentioned determinants as potential motivators of inward FDI in BRICS (i.e. Brazil, Russia, India, China and South Africa) member states. The stable macro-economic conditions and lower inflation have also enabled some countries in sub-Saharan Africa (SSA), such as Angola, Botswana and Kenya, to attract Chinese FDI in the construction industry (Mlachila \& Takebe 2011). In the case of Botswana, in particular, additional significant pull determinants for Chinese FDI include economic liberalisation, deregulation, privatisation and preferential trade schemes.

Many other studies in the FDI literature (e.g. Bevan \& Estrin 2004; Campa 1993; Dunning 1973; Erdal \& Tataoglu 2002; Esiyok 2011; Nonnemberg \& Cardoso de Mendonça 2004; Tokunbo \& Lloyd 2009) also emphasise the significance of host market determinants in attracting inward FDI. Such studies find a positive relationship between host market determinants and inward FDI. For instance, Bevan and Estrin (2004) investigated the determinants of FDI into European transition economies. Their findings suggest that inward FDI is determined by host market determinants, such as geographical proximity, market size and labour cost per unit. The findings of Bevan and Estrin (2004) also validated the results of Nonnemberg and Cardoso de Mendonça (2004) who established a positive correlation between inward FDI and host market determinants, such as trade openness and macro-economic performance.

The cost of borrowing correspondingly plays a significant role in determining inward FDI in a country. For instance, a lower interest rate in the host country lures FDI into the country. This is supported by Tokunbo and Lloyd (2009) who revealed that the host country interest rate is the main determinant of inward FDI in Nigeria. Openness of the host country to inward FDI is also regarded as an important determinant of inward FDI. In fact, a country that is more open attracts increased inward FDI because of its ability to provide a springboard for export-oriented foreign direct investors in the host country (Feng 2011).

Infrastructure and labour cost also influence the level of inward FDI in a country. In this regard, scholars, such as Deichmann, Karidis and Sayek (2003) and Esiyok (2011), suggest a positive relationship between improved infrastructure and the host country's inward FDI. As the primary aim of foreign direct investors is to make profits, it is generally assumed that low labour costs positively affect inward FDI into the host country (Liu, Daly \& Varua 2012).

\section{Overview of the African retail sector}

The African retail sector is characterised by multiple semiformal and informal retailers who sell mostly groceries. In fact, a report of 14 countries in SSA by Nielsen (2015) reveals that the informal retail sector accounts for approximately $50 \%$ of the region's consumer expenditure on merchandises. 
The report further exposes that modern trade in SSA is still in its infancy and about $80 \%$ of consumers in the region conduct their shopping from traditional channels, such as table tops (i.e. roadside stands intended to capture passing consumers and local traders). For instance, Nigeria had only two shopping malls in 2012 and, although the country hosts a few of Africa's most prominent supermarket chains, it has more than 700000 traditional outlets for soft drinks alone (AT Kearney 2014).

Even though semi-formal and informal retail activities are dominant in the African retail sector, international and regional retailers are increasingly being attracted to Africa's property markets and focusing on retail sector development. Price-waterhouse coopers (PWC 2013) expects a remarkable growth, at least until 2025, in the African retail market. This expectation is based on expanding demographics together with growing consumer demand. Validating the expectation of PWC (2013), the findings of Klynveld Peat Marwick Goerdeler (KPMG) (2015) attribute the expeditious economic growth and demographics in Africa to the expectation of increased consumer spending.

In terms of Africa's retail trade inward FDI, Figure 2 shows that a large proportion of the investments in 2018 were received by Morocco, South Africa, Mauritius and Egypt. Morocco, for instance, received 323 retail foreign affiliates and 220 retail parent companies in 2018 alone. This is, however, fewer in comparison with South Africa, which received 319 retail foreign affiliates and 258 retail parent companies during the same period. A very small proportion of the retail trade inward FDI is received by countries, such as Zimbabwe, Madagascar, Malawi and Ethiopia. The numbers of foreign affiliates received by these countries range from 24 to 32 , whilst the numbers of parent companies range from 20 to 23 . It is surprising though to find Ethiopia in the same category as countries, such as Malawi, Madagascar and Zimbabwe, given its impressive level of economic growth over the past few decades.

Africa's retail outward FDI, in contrast, originates mainly from South Africa and Mauritius (see Figure 3). These two countries account for a larger proportion of Africa's outward retail foreign affiliates and retail parent companies. For instance, 114 retail foreign affiliates and 66 retail parent companies originated from South Africa in 2018. Likewise, 91 retail foreign affiliates and 56 retail parent companies originated from Mauritius during the same period. The numbers of both retail foreign affiliates and parent companies originating from all the other African countries, during the year 2018, range from 0 to 34

Nonetheless, entering the African retail market is not free from challenges. In this regard, foreign direct investors are likely to encounter the following barriers (Coetzee, Bezuidenhout \& Mhonyera 2020): political and economic instability; poorly developed infrastructure; weak industrial and manufacturing base; lack of policy consistency; differences in consumer behaviour; cultural differences; and fragmented retail markets. Therefore, in order to make inroads into Africa's retail market, investors ought to meticulously examine the nature and geographical locations of trade outlets in potential host countries, the type of products they offer, the size of the host market and the characteristics of their targeted clientele. Furthermore, potential foreign direct investors should analyse the accessibility and potential revenues of each outlet and create an effective as well as profitable product distribution strategy.

\section{Overview of the South African retail sector}

South Africa has a highly developed retail market, which is considered to be on par with some of the world's most developed countries. A substantial portion of the South African economy is driven by consumer spending. Consequently, retail sales are used as an essential economic indicator (Cooke, Prabu \& Steele 2016). As an outcome of its large impression on urban and rural areas, the South African retail sector also contributes to the sustenance of many South Africans by employing a significant number of the country's labour force. In fact, the sector has the potential to create sustainable employment and to integrate untrained workers in the country through training them, on the job, to

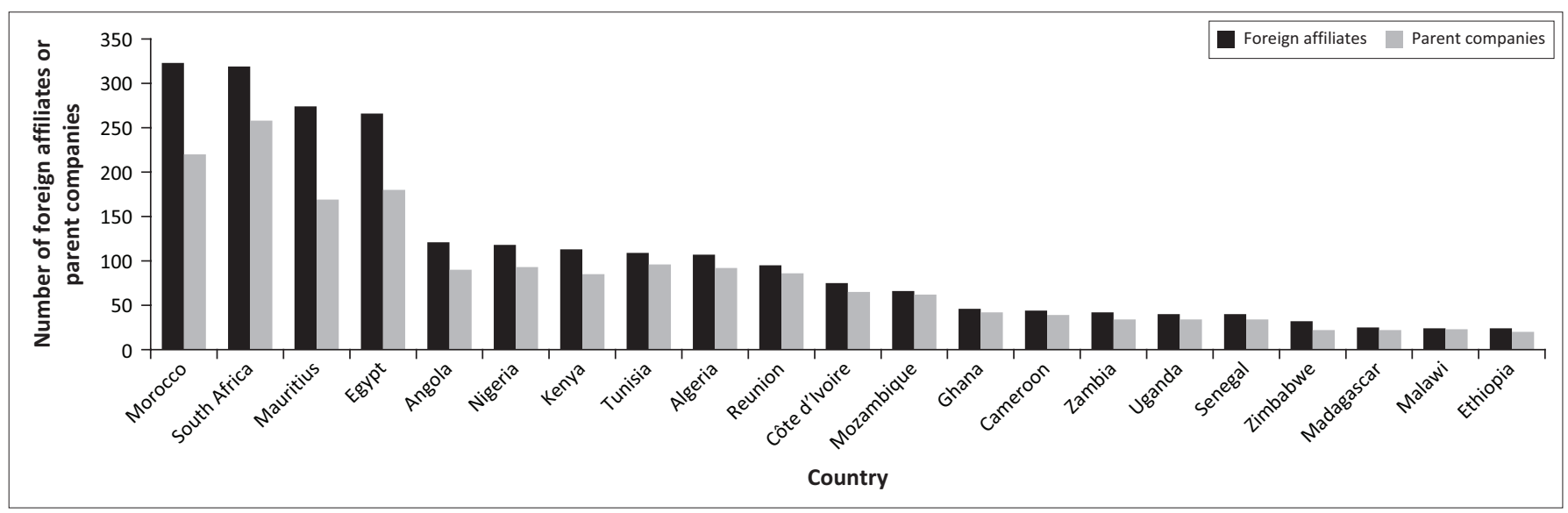

Source: International Trade Centre, 2019, Investment map: Locations competing for investment, viewed 26 March 2019, from https://www.intracen.org/itc/market-info-tools/statistics-inwardindustry-country/

FIGURE 2: Africa's retail trade inward foreign direct investment by host country in 2018. 


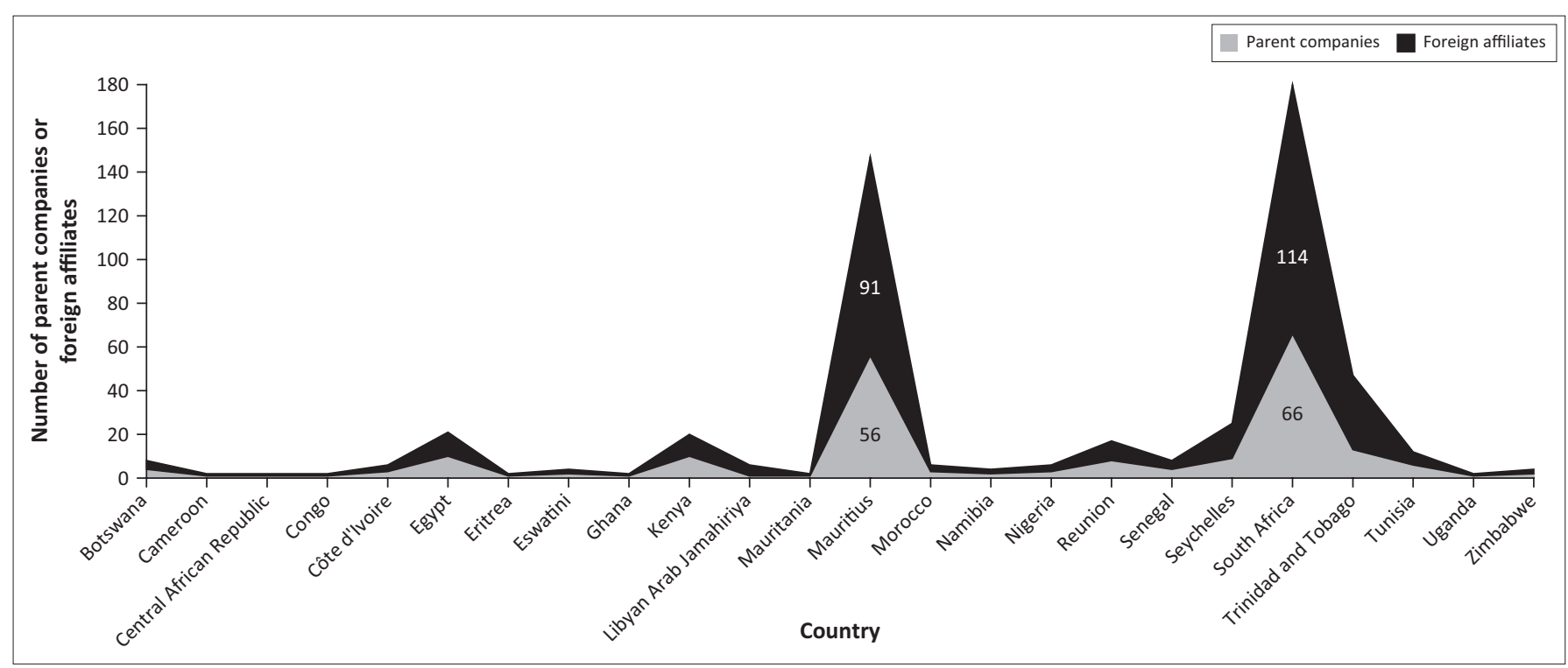

Source: International Trade Centre, 2019, Investment map: Locations competing for investment, viewed 26 March 2019, from https://www.intracen.org/itc/market-info-tools/statistics-inwardindustry-country/

FIGURE 3: Africa's retail trade outward foreign direct investment by investing country in 2018.

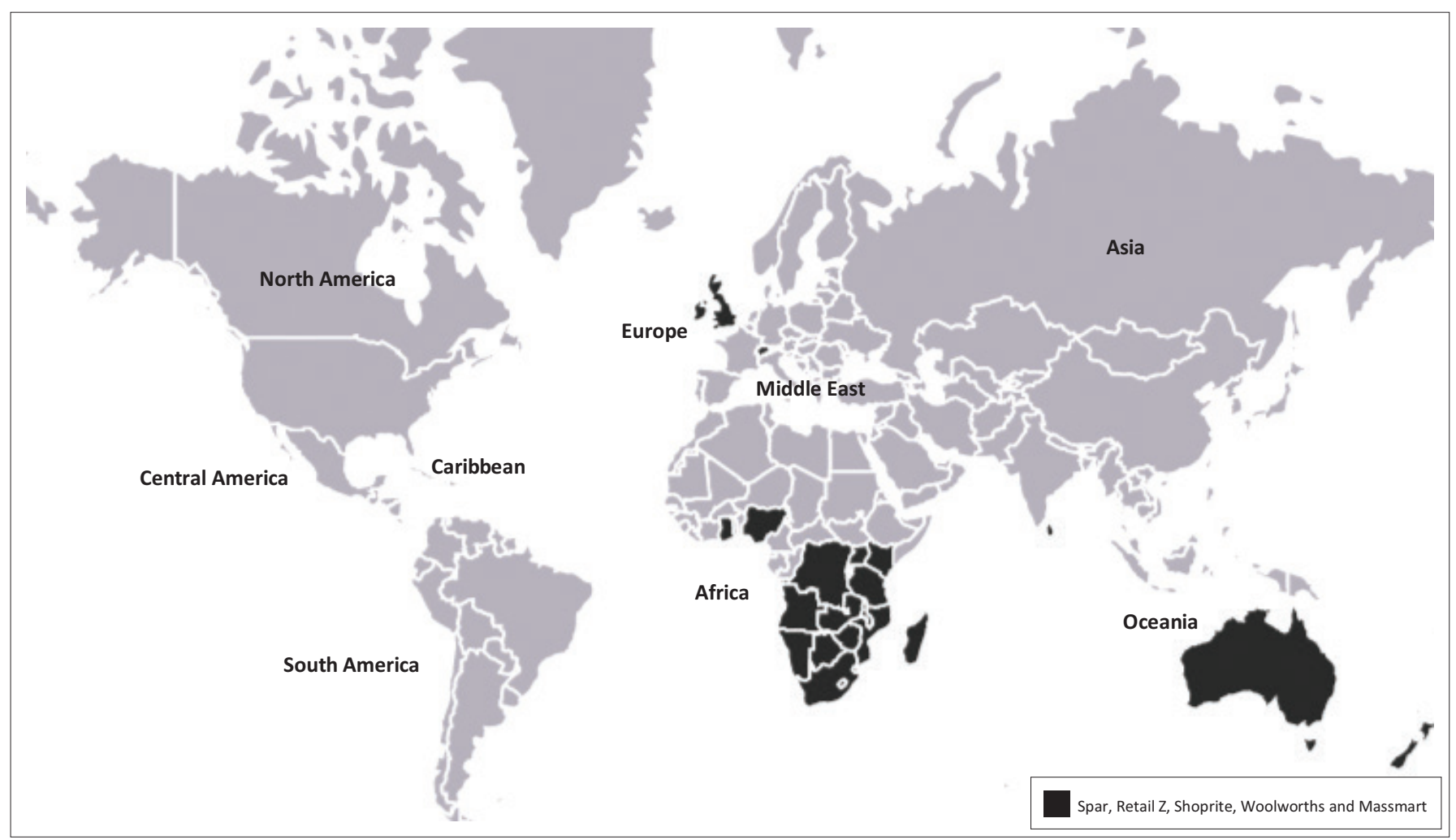

FIGURE 4: Combined footprint of five major South African retail enterprises with foreign direct investment in Africa.

become cashiers and merchandisers in stores (Malgas, Khatle \& Mason 2015).

Although South Africa possesses a highly developed retail sector, the country's retail market is highly saturated. This is supported by Malgas et al. (2015) who stated that the South African retail sector highlights a mature market with a high concentration of a small number of large retailers, such as Shoprite. Therefore, in terms of retail expansion, African countries such as Nigeria would be a better option in comparison with South Africa. In fact, the saturation of the domestic retail market has led to an increase in the number of South African retailers establishing retail outlets in other African countries.

The combined footprint of the five major South African retail enterprises, considered in this article, with FDI in Africa is shown in Figure 4. It is apparent that South African retail already has a substantial footprint in the African continent, and the country's FDI footprint is concentrated in the 
Southern and Eastern countries of the SSA. Furthermore, the majority of the SSA countries in which South Africa's retail investments are dominant, are members of the Southern Africa Development Conference. In addition to its footprint in Africa, one of the South African retail enterprises, Spar, has retail operations in Europe (i.e. Ireland, England and Switzerland) and in one of the Asian countries (i.e. Sri Lanka). Similarly, Woolworths has retail operations in Oceania (i.e. Australia and New Zealand).

When making inroads into the African market, these major South African retailers (see Figure 4) exploit retail markets that have been characterised by large open-air markets and informal trading activities (Dakora, Bytheway \& Slabbert 2010). Other foreign market entry modes employed by South African retailers include franchising and partnerships. However, the inclination is commonly towards full ownership, unless that is prohibited by the domestic laws of the particular host country (Games 2008).

\section{Research method Considered population}

This research article utilises a mixed-method research technique to identify the determinants of outward FDI decisions of five major South African retail enterprises with a significant FDI footprint in Africa. As mentioned above, the emphasis is on establishing the extent to which push and pull determinants define South African retail sector outward FDI and the challenges faced by South African retailers when investing in Africa's retail sector. Similar to Coetzee et al. (2020), the mixed-method approach involved: (1) an in-depth case study of each of the five major South African retail enterprises considered in this article; and (2) semi-structured interviews conducted with the respective retail enterprise officials responsible for expansion into Africa.

The multiple case study approach makes it possible to establish the determinants that influence outward FDI decisions of major South African retailers investing in Africa and the challenges they faced when investing in Africa's retail market. According to Niewenhuis (2010), multiple cases are necessary to answer the 'why' and 'how' questions. Furthermore, a multiple case study provides a stronger base for theory building and allows for comparisons across various cases (Kreppel 2012). Similarly, the multiple case study approach allows for an understanding of the uniqueness of a case in all its complexity (Yin 2009). According to Coetzee et al. (2020), a case study does not always have to be a person as it can also be in the form of publications, documents, press releases, emails, letters and so on.

The semi-structured interviews used in this article are based on the following paradigms: ontological position, which assumes that individuals' interpretations, views, experiences and knowledge are important components of the social reality that the research questions intend to examine; epistemological position, which implies that data and knowledge can be generated through talking interactively with people, asking questions and listening in order to gain insights into their personal experiences; the belief that knowledge and evidence are situational, interactional and contextual, which justifies that interviews draw upon the social experiences; and the interpretive paradigm, which motivates for the use of multiple data sources and analysis methods to achieve validity.

Semi-structured interviews allow for flexibility. In this regard, how and when a question is asked are determined by the direction of the interview and not the order in the guideline. For example, if a question is answered before it is asked, it will be skipped in the interview (Bailey 2007). The flexibility of semi-structured interviews is also confirmed by Simmons (2009), who stated that interviews facilitate probing on a topic and changing the direction to pursue emergent issues. However, for semi-structured interviews to be successful, the researcher must ensure that the necessary preparation is conducted before the interview, more creativity and discipline exist during the interview, and that sufficient time is dedicated for analysis and interpretation after the interview (Wengraf 2001).

\section{Research instrument}

In order to create questions that would answer relevant issues, the interview questions were compiled by referring to the objectives that this article seeks to achieve. To allow for the disparities in individual retail enterprises, open-ended questions were used. The questions were grouped into the following categories: (1) background of the retail enterprise, structure and management of its investments in Africa; (2) strategy, which focused on the retail enterprise's specific advantages in Africa; (3) South African retail environment and its role in investment decisions; (4) investment, which focused on how factors such as infrastructure, collaborations with other firms and associated investment risks influence an enterprise's decision to invest in Africa; and (5) current and future plans in which questions were designed to obtain responses on the enterprise's current plans and views of long-term investments in Africa, as well as countries worth investing in.

Prior to conducting the formal interviews, a successful pilot test was conducted with retail experts in order to ensure validity and reliability of the research instrument. In other words, this was performed in order to verify the easiness of comprehending the interview questions and whether the questions would induce the necessary responses required to obtain as much data as possible.

The collected desk research and the semi-structured interview data were used to compile the final findings presented in this article. Therefore, in order to organise and prepare the data for analysis, the data obtained from desk research were typed 
and the audio recordings from the semi-structured interviews were transcribed. After cautiously reading through the organised data to obtain a general idea of what the data were indicative of, it was organised into categories, and a theme (see Figures 5 and 6) was allocated to each category (i.e. coding).

\section{Ethical consideration}

Ethical approval to conduct the study was obtained from the North-West University, South Africa (Ethical clearance number: EMS16/07/21-04-02) on 12 August 2016.

\section{Results and discussions}

The results of the determinants of outward FDI decisions of major South African retailers, with a substantial FDI footprint in Africa, and the challenges they faced when investing in Africa's retail market are presented and discussed in this section. In this regard, the results are divided into push and pull determinants, as well as the challenges faced by South African retailers when investing in Africa's retail market.

\section{Push determinants}

As shown in Figure 5, all of the major South African retailers consider market-seeking as an extremely significant push determinant when making their FDI decisions. Hence, the saturation of the South African retail market plays a major role in motivating domestic retailers to expand further north into other African countries. The African market offers South African retailers new, untapped formal retail markets with less competition from other formal retailers relative to the home market. As the South African retail market has increasingly become saturated for most retail categories, expanding into Africa is also regarded as a strategic move aimed at creating future retail markets and generating sustainable retail commercial activities. However, retailers such as Shoprite, that also specialise in health and beauty products, acknowledge that there are still voluminous growth opportunities for such retail categories in the domestic market.

Whilst Spar considers the resource-seeking push determinant as moderately significant in its outward FDI decisions, all the

\begin{tabular}{|c|c|c|c|c|c|}
\hline & \multicolumn{5}{|c|}{ Market-seeking } \\
\hline & 1 (Not significant) & $\longleftarrow$ & - & $\longrightarrow$ & 5 (Extremely significant) \\
\hline Spar & - & - & - & - & $\phi$ \\
\hline Retail Z & - & - & - & - & $\phi$ \\
\hline Shoprite & - & - & - & - & $\phi$ \\
\hline Woolworths & - & - & - & - & $\phi$ \\
\hline \multirow[t]{3}{*}{ Massmart } & - & - & - & - & $\phi$ \\
\hline & \multicolumn{5}{|c|}{ Resource-seeking } \\
\hline & 1 (Not significant) & $\longleftarrow$ & 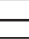 & $\longrightarrow$ & 5 (Extremely significant) \\
\hline Spar & - & - & $\phi$ & - & - \\
\hline Retail Z & - & $\phi$ & - & - & - \\
\hline Shoprite & - & $\phi$ & - & - & - \\
\hline Woolworths & - & $\phi$ & - & - & - \\
\hline \multirow[t]{3}{*}{ Massmart } & - & $\phi$ & - & - & - \\
\hline & \multicolumn{5}{|c|}{ Efficiency-seeking } \\
\hline & 1 (Not significant) & $\longleftarrow$ & 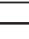 & $\longrightarrow$ & 5 (Extremely significant) \\
\hline Spar & - & - & - & $\phi$ & - \\
\hline Retail Z & - & - & - & - & $\phi$ \\
\hline Shoprite & - & - & - & $\phi$ & - \\
\hline Woolworths & - & - & - & $\phi$ & - \\
\hline \multirow[t]{3}{*}{ Massmart } & - & - & - & $\phi$ & - \\
\hline & \multicolumn{5}{|c|}{ Strategic asset-seeking } \\
\hline & 1 (Not significant) & 4 & - & $\longrightarrow$ & 5 (Extremely significant) \\
\hline Spar & - & - & $\phi$ & - & - \\
\hline Retail Z & - & - & $\phi$ & - & - \\
\hline Shoprite & - & - & - & $\phi$ & - \\
\hline Woolworths & - & - & $\phi$ & - & - \\
\hline \multirow[t]{3}{*}{ Massmart } & - & - & - & $\phi$ & - \\
\hline & \multicolumn{5}{|c|}{ Ownership advantages } \\
\hline & 1 (Not significant) & $\longleftarrow$ & 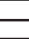 & $\longrightarrow$ & 5 (Extremely significant) \\
\hline Spar & - & - & - & $\phi$ & - \\
\hline Retail Z & - & - & - & $\phi$ & - \\
\hline Shoprite & - & - & - & $\phi$ & - \\
\hline Woolworths & - & - & - & $\phi$ & - \\
\hline Massmart & - & - & - & $\phi$ & - \\
\hline
\end{tabular}

Five-point Likert significance scale: 1 (not significant), 2 (slightly significant), 3 (moderately significant), 4 (significant) and 5 (extremely significant).

$\$$, the level of significance in terms of the five-point Likert significance scale.

FIGURE 5: Push determinants of outward foreign direct investment of major South African retailers investing in Africa. 
other retailers regard the determinant as slightly important. The retailers, however, accept that the resource capabilities of a potential host country play a major role in the selection of a country for retail outward FDI. This emanates from the fact that natural resources drive most African economies.

Efficiency-seeking is considered as a significant determinant for outward FDI decisions by all the retailers, with Retail Z regarding the determinant as extremely important in its outward FDI decisions. Contrary to the theories that point internationalisation to the derivation of benefits from economies of scale, the retailers indicated that they do not prioritise economies of scale in their outward FDI decisions. Instead, they rely on central distribution networks in the regions. In fact, most of the goods traded by the respective retailers in the African countries that they are located in do not originate from South Africa. For instance, South African products constitute little merchandise of Retail Z in its foreign retail outlets.

Strategic asset-seeking is regarded as a moderately significant, outward FDI determinant by Spar, Retail Z and Woolworths, whilst Shoprite and Massmart consider the determinant as significant in their outward FDI decisions. The retailers require some strategic assets in order to augment the ownership advantages required for their long-term expansion plans into the African continent. Such strategic assets can be pursued in the spheres of distribution and supply chain management.

Ownership advantages are considered as a significant determinant by all the five retailers. Compared with domestic retailers in the African host countries they invest in, South African retailers possess ownership advantages, such as company size, and business and organisational intelligence. Accordingly, since there is an increase in outward FDI from South Africa, despite inward FDI surpassing outward FDI, the country falls in stage 3 of the IDP theory (see Figure 1). The retailers highlighted that their retail experience coupled with their respective own branding grants them a competitive edge over local retailers in most of the African countries they possess FDI in. Shoprite, for instance, sells its own brand in stores at competitive prices and ensures that its brand is viewed as that of the specific host country instead of being viewed as a South African brand.

\section{Pull determinants}

In terms of pull determinants, all the five major South African retailers consider market size as a significant determinant in their outward FDI decisions (see Figure 6). As Africa is amongst the fastest growing markets globally, with a young population and rising household income, the retailers acknowledged that the continent offers an attractive and extremely untapped potential formal retail market. In addition, investing in countries with a large and young population can possibly be viewed as strategic and assists in securing future retail markets for their retail enterprises.
The political and macro-economic environment also plays an integral role in the process of selecting potential host countries. With the exception of Retail $\mathrm{Z}$ and Shoprite, which view this determinant as moderately significant, all the other retailers view political and macro-economic stability as significant in their outward FDI decisions. However, retailers such as Shoprite maintain that it is beneficial to not hold political agenda and not to participate in the domestic political affairs of the host country.

The availability and costs of labour are considered as significant by Retail Z, whilst all the other retailers regard the determinant as moderately significant. The retailers recognise that the labour costs in South Africa are already relatively high compared with most of its African counterparts. In fact, favourable labour practices in other African countries, particularly low wages, have lured some of the South African retailers to invest in the continent. Whilst Africa's labour force is growing, in countries where the expertise required is not available, retailers such as Shoprite move into the host country with skilled personnel from South Africa and train local personnel on the job.

There are mixed considerations with regard to the importance of the availability of infrastructure in outward FDI decisions of the five major South African retailers. Spar regards this determinant as significant in its FDI decisions. Woolworths and Massmart, however, regard the availability of infrastructure as moderately significant, whilst Retail $\mathrm{Z}$ and Shoprite consider the determinant as slightly significant. For Retail Z and Shoprite, in particular, lack of infrastructure such as roads, water and electricity does not stop the retailers when deciding to invest in Africa. This is because the retailers initially target major cities and make use of backup plans such as investing in own boreholes, water purification plants and generators.

Nevertheless, infrastructural development has been identified as an important factor in attracting retail inward FDI. For example, Rwanda upgraded its road system, and this has made the country a regional coordination centre for East Africa (Global Perspectives 2014). Likewise, developments in Ethiopia's infrastructure, such as roads, power and telecommunications, have resulted in exponential growth in its retail sector (AT Kearney 2014).

Profitability and growth prospects in the host country are considered as significant in the outward FDI decisions of Shoprite and Massmart. The rest of the retailers regard this determinant as extremely significant. Whilst there is a consensus amongst the retailers that the motive for retail outward FDI can be singled out as the desire to make profits, retailers such as Spar do not require a retail outlet in a host country to be profitable in the short-term for it to be thought of as a worthwhile investment. Therefore, if a country has the potential to generate profits and offers growth prospects in the long run, it will be considered for investment. 


\begin{tabular}{|c|c|c|c|c|c|}
\hline & \multicolumn{5}{|c|}{ Market size } \\
\hline & 1 (Not significant) & $\longleftarrow$ & 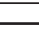 & $\longrightarrow$ & 5 (Extremely significant) \\
\hline Spar & - & - & - & $\phi$ & - \\
\hline Retail Z & - & - & - & $\phi$ & - \\
\hline Shoprite & - & - & - & $\phi$ & - \\
\hline Woolworths & - & - & - & $\phi$ & - \\
\hline \multirow[t]{3}{*}{ Massmart } & - & - & - & $\phi$ & - \\
\hline & \multicolumn{5}{|c|}{ Political and macro-economic stability } \\
\hline & 1 (Not significant) & $\longleftarrow$ & 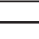 & $\longrightarrow$ & 5 (Extremely significant) \\
\hline Spar & - & - & - & $\phi$ & - \\
\hline Retail Z & - & - & $\phi$ & - & - \\
\hline Shoprite & - & - & $\phi$ & - & - \\
\hline Woolworths & - & - & - & $\phi$ & - \\
\hline \multirow[t]{3}{*}{ Massmart } & - & - & - & $\phi$ & - \\
\hline & \multicolumn{5}{|c|}{ Availability and costs of labour } \\
\hline & 1 (Insignificant) & 4 & 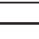 & $\longrightarrow$ & 5 (Extremely significant) \\
\hline Spar & - & - & $\phi$ & - & - \\
\hline Retail Z & - & - & - & $\phi$ & - \\
\hline Shoprite & - & - & $\phi$ & - & - \\
\hline Woolworths & - & - & $\phi$ & - & - \\
\hline \multirow[t]{3}{*}{ Massmart } & - & - & $\phi$ & - & - \\
\hline & \multicolumn{5}{|c|}{ Availability of infrastructure } \\
\hline & 1 (Not significant) & $\longleftarrow$ & - & $\longrightarrow$ & 5 (Extremely significant) \\
\hline Spar & - & - & - & $\phi$ & - \\
\hline Retail Z & - & $\phi$ & - & - & - \\
\hline Shoprite & - & $\phi$ & - & - & - \\
\hline Woolworths & - & - & $\phi$ & - & - \\
\hline \multirow[t]{3}{*}{ Massmart } & - & - & $\phi$ & - & - \\
\hline & \multicolumn{5}{|c|}{ Profitability and growth prospects } \\
\hline & 1 (Not significant) & 4 & 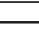 & $\longrightarrow$ & 5 (Extremely significant) \\
\hline Spar & - & - & - & - & $\phi$ \\
\hline Retail Z & - & - & - & - & $\phi$ \\
\hline Shoprite & - & - & - & $\phi$ & - \\
\hline Woolworths & - & - & - & - & $\phi$ \\
\hline \multirow[t]{3}{*}{ Massmart } & - & - & - & $\phi$ & - \\
\hline & \multicolumn{5}{|c|}{ Trade and investment openness } \\
\hline & 1 (Not significant) & $\longleftarrow$ & - & $\longrightarrow$ & 5 (Extremely significant) \\
\hline Spar & - & - & - & $\phi$ & - \\
\hline Retail Z & - & - & - & $\phi$ & - \\
\hline Shoprite & - & - & - & $\phi$ & - \\
\hline Woolworths & - & - & - & $\phi$ & - \\
\hline Massmart & - & - & - & $\phi$ & - \\
\hline
\end{tabular}

Five-point Likert significance scale: 1 (not significant), 2 (slightly significant), 3 (moderately significant), 4 (significant) and 5 (extremely significant).

$\phi$, the level of significance in terms of the five-point Likert significance scale.

FIGURE 6: Pull determinants of outward foreign direct investment of major South African retailers investing in Africa. Five-point Likert significance scale: 1 (not significant), 2 (slightly significant), 3 (moderately significant), 4 (significant) and 5 (extremely significant).

All the major retailers consider the trade and investment openness determinant as significant in their retail outward FDI decisions. The retailers revealed discrepancies in investing in countries bordering South Africa and those that are further away. For instance, the trade and investment agreements between South Africa, Botswana, Lesotho, Namibia and Swaziland make it much easier for South African retailers to set-up retail outlets, as well as for consumers from these countries to easily adapt to South African trends. In contrast, customs and taxation practices for countries further away from South Africa make it difficult for South African retailers to penetrate those retail markets. In addition, some countries might demand certain after-tax contributions aimed at local supply and skills development, as well as corporate social investment.
Amongst other pull determinants, property developers also play a critical role in shaping the investment decisions of some of the South African retailers. For instance, the retailers highlighted that they are sometimes approached by property developers such as RMB Westport to determine their willingness to conduct retail operations and lease space at shopping malls that the developers wish to develop in identified African countries. Prior to approaching the retailers, the property developers conduct market research to find viable sites and potential retail markets. In some cases, retailers and developers also engage in joint ventures to build shopping centres. Such joint ventures include Resilient Africa (a joint venture between Standard Bank and Shoprite), which involves developing of shopping malls that do not exceed $14000 \mathrm{~m}^{2}$ in Nigeria (Mhlaka 2015). 


\section{Challenges faced when investing in Africa's retail market}

Investing in Africa's retail markets is not free from challenges. For instance, the major South African retailers noted that most of the domestic retailers investing in Africa are pioneers of formal retail in most countries they invest in. This generates risks such as reluctance of customers to shift from their local informal markets to purchasing merchandise at formal retail shops. In addition, customers in some of the African countries, such as Egypt, are loyal to their own brands and people. Therefore, they would rather buy from another domestic retailer instead of supporting a foreign-owned retail outlet.

The political instability and bureaucratic procedures also constrain the ease of business operations in some African countries. Consequently, the level of uncertainty and corruption is amplified, with some countries requiring inducement of administrative officials in order to conduct business operations in such countries. Even in some cases in which corrupt tendencies are not rife, bureaucratic procedures (e.g. surrounding the expropriation of profits and requirements for doing business) in certain African countries culminate in increased operational costs and reduce the willingness of South African retailers to invest in such countries.

For some of the major South African retailers such as Retail Z and Shoprite, the lack of infrastructure such as roads, railway, telecommunication, internet, water and electricity has little influence on their investment decisions. This is because they mainly invest in major cities, which have better services or advanced back-up plans, such as self-sustaining malls equipped with water purification plants, generators and roads to the malls. However, this makes investments more expensive for some retailers and limits the geographical locations that they can invest in.

Another key challenge faced by South African retailers when investing in Africa is foreign currency deficit or convertibility risk. This normally occurs when the central bank of the host country is unable to organise the necessary foreign currency reserves required to convert local funds into foreign currency in order to allow the South African retailers to repatriate their profits to South Africa. Moreover, if the host country's currency depreciates, intermediate inputs and warehouse supplies become more expensive.

Other challenges faced by South African retailers when investing in Africa include: macro-economic instability in some African countries such as Zimbabwe, transaction costs in the form of high tariffs that most African countries charge for the importation of goods into their territories, decline in purchasing power of oil-based economies such as Angola and Nigeria because of fluctuations in oil prices in recent years, divergences in South Africa's customs and taxation practices with those of African countries further north, differences in rules and regulations (e.g. various liquor laws across the continent), and cultural and language barriers experienced in a number of African countries.

\section{Conclusions and recommendations}

Although there has been a robust expansion in the South African retail sector outward FDI and that of Africa in general, the empirical literature on retail sector outward FDI from the perspective of African countries is sparse. This article seeks to contribute to the knowledge base and to inspire debate on retail sector outward FDI from the perspective of African countries. Therefore, a mixed-method research technique is employed to identify the determinants of outward FDI decisions and challenges faced by five major South African retail enterprises with a significant FDI footprint in Africa. The results reveal a general consensus amongst the retailers that both push and pull determinants shape, with varying levels of significance, the investment decisions of South African retailers when contemplating to invest in Africa.

For all the five major retailers considered in this article, the most significant push determinants were identified as market-seeking, efficiency-seeking and ownership advantages. Similarly, the most significant pull determinants included market size, political and macro-economic stability, profitability and growth prospects, and trade and investment openness. Other push determinants such as resource-seeking and strategic asset-seeking, as well as pull determinants such as the availability and cost labour and the availability of infrastructure, are considered slightly to moderately significant in the retailers' outward FDI decisions. Therefore, such determinants do not stop the retailers when deciding to invest in Africa's retail sector.

Whilst Africa is a lucrative market with many opportunities for all types of retailers, expanding into the continent is not without its own challenges. The retailers expressed that, although the risk of investing in the African retail sector differs from country to country, it is commonly centred on the lack of infrastructure, political uncertainty and bureaucratic procedures. Other challenges faced by the retailers when investing in Africa include: the reluctance of customers to shift from their local informal markets to formal retail markets, foreign currency deficit or convertibility risk, macroeconomic instability, transaction costs, divergences in home and host country's customs and taxation practices, differences in rules and regulations across African countries, and cultural and language barriers experienced in various African countries.

Despite the challenges mentioned above, all the major retailers revealed that they currently have plans of expanding and establishing new retail outlets in a number of countries in Africa, which include Ivory Coast, Ethiopia, Kenya, Tanzania, Nigeria and Zambia. Their economies are some of the fastest growing on the continent and elsewhere. 
Nigeria and Ethiopia, in particular, are the most populous countries in Africa and have large untapped potential retail markets because of the relatively non-existent formal retail sector in these countries.

This article suggests that, whilst investment in Africa is sustainable, it is country-specific and each country in Africa is different. Accordingly, a one size fits all approach is not applicable in African countries because of the inherent cultural and macro-economic disparities. As a result, retailers considering to invest in Africa ought to evaluate each potential host country based on its own merits, conditions and individual needs. In addition, market research is critical before embarking on an investment. This can be achieved, for instance, by assessing the performance of international organisations operating in a potential host country and by sending own market research personnel to visit the host country and examine the potential places for business operations.

Future research should be committed towards investigating the success or failure of South African retail outward FDI in Africa. Furthermore, the role of incentives in attracting South African retail outward FDI in African countries and the significance of South African retail outward FDI to local economies in Africa can be evaluated. Another line of conceptualisation would be to consider a large multinational sample consisting of retailers from both developed and developing countries in order to determine whether their retail outward FDI decisions are influenced by similar push and pull determinants.

\section{Acknowledgements}

Darlington Chizema acknowledges the financial support received from the North-West University (NWU) towards this study. Opinions expressed and conclusions arrived at are those of the authors and should not necessarily be attributed to the NWU.

\section{Competing interests}

The authors have declared that no competing interests exist.

\section{Authors' contributions}

This article is based on a masters' dissertation of D.C., E.P.J.K., and H.B. assisted with the conceptualisation and supervision of the study and G.M. assisted with writing up and compilation of this article.

\section{Funding information}

This research received no specific grant from any funding agency in the public, commercial or not-for-profit sectors.

\section{Data availability statement}

Data sharing is not applicable to this article as no new data were created or analysed in this article.

\section{Disclaimer}

The views and opinions expressed in this article are those of the authors and do not necessarily reflect the official policy or position of any affiliated agency of the authors.

\section{References}

Aghion, P. \& Howitt, P., 1998, Endogenous growth theory, MIT Press, Cambridge, MA.

Ajayi, S.I., 2005, 'Globalization and equity in sub-Saharan Africa: The myth and reality' in N. Dinello \& L. Squire (eds.), Globalization and equity: Perspectives from the developing world, pp. 67-97, Edward Edgar Publishing, Northampton, MA.

Alagidede, P. \& Mensah, J.O., 2018, 'Construction institutions and economic growth in sub-Saharan Africa', African Review of Economics and Finance 10(1), 136-163.

Ariff, M. \& Lopez, G.P., 2007, Outward foreign direct investment: The Malaysian experience, viewed 24 June 2019, from http://www.icrier.org/pdf/Mohamed\%20 Ariff\%20and\%20Greg\%20Lopez.pdf.

A.T. Kearney, 2014, The 2014 African retail development index: Seizing Africa's retail opportunities, viewed 14 July 2017, from https://preciseethiopia.com/download/ publication/Other Publications/Seizing\%2520Africas\%2520Retail\%2520 Opportunities.pdf\&ved=2ahUKEwiZmZmBzfjtAhVaSxUIHeKbDXUQFjAAeg QIARAB\&usg=AOvVaw0o9VU6OM5JZRsvEiPmpEr3.

Aykut, D. \& Ratha, D., 2004, 'South-South FDI flows: How big are they?', Transnationa Corporations 13(1), 149-176.

Bailey, C.A., 2007, A guide to qualitative research, 2nd edn., Pine Forge Press, Thousand Oaks, CA.

Bevan, A.A. \& Estrin, S., 2004, 'The determinants of foreign direct investment into the European transition economies', Journal of Comparative Economics 32(4), 775-787. https://doi.org/10.1016/j.jce.2004.08.006

Campa, J., 1993, 'Entry of foreign firms in the United States under exchange rate uncertainty', The Review of Economics and Statistics 75(1993), 614-622. https:// doi.org/10.2307/2110014

Carril-Caccia, F. \& Pavlova, E., 2018, Foreign direct investment and its drivers: A globa and EU perspective, viewed 10 April 2018, from https://ideas.repec.org/a/ecb/ ecbart/201800041.html.

Chen, C., 2015, 'Determinants and motives of outward foreign direct investment from China's provincial firms', Transnational Corporations 23(1), 1-28. https://doi. org/10.18356/6002938c-en

Chizema, D., 2018, 'Determining the investment decisions of South African retai firms' FDI into Africa', Unpublished Masters dissertation, North-West University, Potchefstroom.

Coetzee, Z., Bezuidenhout, H. \& Mhonyera, G., 2020, 'Effective strategies followed by multinational enterprises expanding into Africa', Journal of Economic and Financial Sciences 13(1), a511. https://doi.org/10.4102/jef.v13i1.511

Cooke, P.J., Prabu, A. \& Steele, M., 2016, Shopping clean: Retailers and renewable energy, Greenpeace Africa, Johannesburg.

Dakora, E.A.N., Bytheway, A. \& Slabbert, A., 2010, 'The Africanisation of South African retailing: A review', African Journal of Business Management 4(5), 784-754.

Deichmann, J., Karidis, S. \& Sayek, S., 2003, 'Foreign direct investment in Turkey: Regional determinants', Applied Economics 35(16), 1767-1778. https://doi. org/10.1080/0003684032000126780

Denesia, V., 2010, 'Foreign direct investment theories: An overview of the main FD theories', European Journal of Interdisciplinary Studies 2(2), 104-110.

Dunning, J.H., 1973, 'The determinants of international production', Oxford Economic Paper 25(3), 289-336. https://doi.org/10.1093/oxfordjournals.oep.a041261

Dunning, J.H., 1976, Trade, location of economic activity and the multinational enterprise: A search for an eclectic approach, Macmillan, London.

Dunning, J.H., 1993, Global business: The challenge of 1990, Routledge, London.

Dunning, J.H., 1995, 'Reappraising the eclectic paradigm in an age of alliance capitalism', Journal of International Business Studies 26(3), 461-491. https://doi. org/10.1057/palgrave.jibs.8490183

Dunning, J.H. \& Narula, N. (eds.), 1996, Foreign direct investment and governments, Routledge, London.

Durán, J.J. \& Úbeda, F., 2005, 'The investment development path of newly developed countries', The International Journal of the Economics of Business 12(1), 123-137. https://doi.org/10.1080/1357151042000323076

Erdal, F. \& Tataoglu, E., 2002, 'Locational determinants of foreign direct investment in an emerging market economy: Evidence from Turkey', Multinational Business Review 10(1), 21-27.

Esiyok, B., 2011, Determinants of foreign direct investment in Turkey: A panel study approach, viewed 15 April 2018, from https://mpra.ub.uni-muenchen.de/36568/ 1/MPRA_paper_36568.pdf.

Feng, Y., 2011, 'Foreign direct investment in China's service industry: Effects and determinants', China: An International Journal 9(1), 144-163. https://doi. org/10.1142/S0219747211000082

Games, D., 2008, 'The South African retail sector in Africa', in N. Grobbelaar \& $\mathrm{H}$. Besada (eds.), Unlocking Africa's potential: The role of corporate South Africa in strengthening Africa's private sector, South African Institute of International Affairs, Johannesburg. 
Global Perspectives, 2014, Emerging markets: The new frontiers for real estate, National Association of Realtors, Chicago, IL.

International Trade Centre, 2019, Investment map: Locations competing for investment, viewed 26 March 2019, from https://www.intracen.org/itc/marketinfo-tools/statistics-inward-industry-country/.

Kayam, S.S., 2009, Home market determinants of FDI outflows from developing and transition economies, viewed 24 June 2019, from http://mpra.ub.uni-muenchen. de/16781/.

Kilic, C., Bayar, Y. \& Arica, F., 2014, 'Effects of currency unions on foreign direct investment inflows: The European economic and monetary union case', International Journal of Economics and Financial Issues 4(1), 8-15.

KMPG, 2015, Sector report: The African consumer and retail, KPMG, Johannesburg.

Kreppel, D.H.H., 2012, 'Determinants of outward foreign direct investment from BRIC countries: An explorative study', International Journal of Emerging Markets 7(1), 4-30. https://doi.org/10.1108/17468801211197897

Liu, K., Daly, K. \& Varua, M.E., 2012, 'Regional determinants of foreign direct investment in manufacturing industry', International Journal of Economics and Finance 4(12), 178-192. https://doi.org/10.5539/ijef.v4n12p178

Malgas, B., Khatle, T. \& Mason, B., 2015, Retail's contribution to and strategies for job creation and retention, Wholesale \& Retail Sector Education and Training Authorities, Cape Town.

Masron, T.A. \& Shahbudin, A.S., 2010, 'Push factors of outward FDI: Evidence from Malaysia and Thailand', Journal of Business and Policy Research 5(1), 54-68.

Mhlaka, R., 2015, 'Africa retail is a good bet: Saturation of the South African market driving capital across the continent', Property Mogul Issue 5(1), 8-9.

Mlachila, M. \& Takebe, M., 2011, FDI from BRICs to LICs: Emerging growth driver?, International Monetary Fund, Washington, DC.

Müller, T., 2006, 'Analysing modes of foreign entry: Greenfield investment versus acquisition', Review of International Economics 15(1), 93-111. https://doi. org/10.1111/j.1467-9396.2006.00634.x

Myers, H. \& Alexander, N., 2007, 'The role of retail internationalisation in the establishment of a European retail structure', International Journal of Retail and Distribution Management 35(1), 6-19. https://doi.org/10.1108/09590550710722314

Nielsen, 2015, Africa: How to navigate the retail distribution labyrinth, Nielsen Johannesburg.

Niewenhuis, J., 2010, 'Introducing qualitative research', in K. Maree (ed.), First steps in research, pp. 69-97, Van Schaik, Pretoria.

Nonnemberg, M.B. \& Cardoso de Mendonça, M.J., 2004, The determinants of foreign investment in developing countries, viewed 10 April 2018, from http://www. anpec.org.br/encontro2004/artigos/A04A061.pdf.

OECD, 2002, OECD benchmark definition of foreign direct investment, OECD Publishing, Paris.
Paprzycki, R. \& Fukao, K., 2005, The extent and history of foreign direct investment in Japan, viewed 12 April 2018, from http://hi-stat.ier.hit-u.ac.jp/research/ discussion/2005/pdf/D05-84.pdf.

Pletikosa, D., 2015, 'Business performance, investments and competitiveness of Istrian hotel industry', University of Tourism and Management Journal of Economics 6(2), 307-319, viewed 26 April 2018, from http://hdl.handle.net/10419/146365.

PWC, 2013, Future prospects in Africa for the transportation \& logistics industry: Africa gearing up, Price-waterhouse coopers, Johannesburg.

Qiu, L.D. \& Wang, S., 2011, 'FDI policy, greenfield investment and cross-border mergers', Review of International Economics 19(5), 836-851. https://doi. org/10.1111/j.1467-9396.2011.00984.x

Ranjan, V. \& Agarwal, G., 2011, 'FDI inflow determinants in BRIC countries: A pane data analysis', International Business Research 4(4), 255-263. https://doi. org/10.5539/ibr.v4n4p255

Shoprite, 2019, Integrated Annual Report, viewed 10 April 2018, from https:// www.shopriteholdings.co.za/content/dam/MediaPortal/LatestIntegrateReport/ IR2019/Shoprite_IR_2019_Full.pdf.

Simmons, H., 2009, Case study research in practice, Sage, London.

Surdu, I., Mellahi, K. \& Glaister, K., 2018, 'Emerging market multinationals international equity-based entry mode strategies: Review of theoretical foundations and future directions', International Marketing Review 35(2), 342-359. https://doi. org/10.1108/IMR-10-2015-0228

Te Velde, D.W., 2006, Foreign direct investment and development: An historical perspective, Overseas Development Institute, London.

Tokunbo, S.O. \& Lloyd, A.A., 2009, 'Foreign direct investment and exchange rate volatility in Nigeria', International Journal of Applied Econometrics and Quantitative Studies 9(2), 1-13.

UNCTAD, 1998, World investment report: Trends and determinants, UNCTAD Publishing, Geneva.

UNCTAD, 1999, Word investment report, UNCTAD Publishing, Geneva.

UNCTAD, 2002, Foreign direct investment for development: Maximising benefits Minimising costs, UNCTAD Publishing, Geneva.

UNCTAD, 2004, World investment report: The shift towards services, UNCTAD Publishing, Geneva.

UNCTAD, 2019, World investment report: Special economic zones, UNCTAD Publishing, Geneva.

UNCTAD, 2020, World investment report: International production beyond the pandemic, UNCTAD Publishing, Geneva.

Wengraf, T., 2001, Qualitative research interviewing, Sage, London.

Yin, R.K., 2009, Applications of case study research, 2nd edn., Sage, London. 